\title{
Ovarian and endocrine responses in the cat after coitus*
}

\section{M. Shille†ף, Coralie Munro†, Susan Walker Farmer $\ddagger$, H. Papkoff $\ddagger \S$ and G. H. Stabenfeldt $\uparrow$}

$\dagger$ Department of Reproduction, School of Veterinary Medicine, University of California, Davis, California 95616; $\ddagger$ Hormone Research Laboratory, and §Reproductive Endocrinology Center, University of California, San Francisco, California 93141, U.S.A.

\begin{abstract}
Summary. LH release leading to ovulation was induced in 17 of 29 oestrous periods. The time of ovulation after coitus was determined by histological examination or by observation at laparotomy of ovaries in situ. Histological methods revealed that ovulation was complete in most follicles ( 9 of 13) at $32 \mathrm{~h}$ post coitum and in all follicles that were involved in the ovulatory process by $36 \mathrm{~h}$. When laparotomy was used, no signs of preovulatory change were noted at the first observation time, $22 \mathrm{~h}$ post coitum, but in 4 cycles in which the entire process of ovulation was observed, the ovulatory process occurred between 23 and $28 \mathrm{~h}$ ( 3 follicles), 23 and $27 \mathrm{~h}$ ( 2 follicles), 25 and $28 \mathrm{~h}$ ( 3 follicles), and 25 and $29 \mathrm{~h}$ ( 3 follicles) post coitum. The first ovulatory process noted was complete at $25 \mathrm{~h}$ post coitum.

In cats, $\mathrm{LH}$ release continued over a 16-h period before returning to baseline (long surge), values being $616 \pm 180 \mathrm{ng} / \mathrm{ml}$ at $\frac{1}{2} \mathrm{~h}$ and $941 \pm 154 \mathrm{ng} / \mathrm{ml}$ at $2 \mathrm{~h}$ post coitum. In 6 cats the $\mathrm{LH}$ release pattern was limited to a $4-\mathrm{h}$ period (short surge), values being $537 \pm$ $218 \mathrm{ng} / \mathrm{ml}$ at $\frac{1}{2} \mathrm{~h}$ and $353 \pm 245 \mathrm{ng} / \mathrm{ml}$ plasma at $2 \mathrm{~h}$ and basal $(49 \pm 18 \mathrm{ng} / \mathrm{ml})$ by $4 \mathrm{~h}$ post coitum. Decreased secretion of oestrogen by follicles in animals undergoing ovulation was first observed at $16 \mathrm{~h}$ post coitum.

It is concluded that coitus induces $\mathrm{LH}$ release within minutes in the cat and that ovulation begins about $24 \mathrm{~h}$ later and finishes by about $32 \mathrm{~h}$ post coitum. Only one coital input can cause $\mathrm{LH}$ release for as long as $16-20 \mathrm{~h}$ although shorter periods of LH release ( $4 \mathrm{~h}$ or less) can result in ovulation.
\end{abstract}

\section{Introduction}

Mating or a comparable stimulus is needed to initiate the neural and endocrine sequences which result in ovulation in the domestic cat (Felis catus) (Longley, 1911), the jaguar (Panthera onca) (Wildt, Platz, Chakraborty \& Seager, 1979) and the puma (F. concolor) (Bonney, Moore \& Jones, 1981). The time and sequence of preovulatory events in the domestic cat have been described from observations of the ovary post mortem (Longley, 1910; Foster \& Hisaw, 1935; Dawson \& Friedgood, 1940 ) or from laparoscopy (Wildt \& Seager, 1978) at timed intervals after coitus. Friedgood \& Dawson (1940) described a degranulation of carmine cells in the anterior hypophysis of cats after coitus, and several authors have followed the changes of luteinizing hormone (LH) in plasma after coitus (Concannon, Hodgson \& Lein, 1980; Shille \& Stabenfeldt, 1980; Wildt, Seager \& Chakraborty, 1980; Johnson \& Gay, 1981b; Wildt, Chan, Seager \& Chakraborty, 1981).

* Reprint requests to Professor G. H. Stabenfeldt, Department of Reproduction, School of Veterinary Medicine, University of California, Davis, California 95616, U.S.A.

T Present address: Department of Reproduction, College of Veterinary Medicine, University of Florida, Gainesville, Florida 32610, U.S.A. 
This report presents a study designed to determine (1) the interval from coitus to ovulation in the cat and (2) the endocrine events that are associated with ovulation. Periovulatory follicular changes are also described. Some of the data have been previously presented (Shille \& Stabenfeldt, 1980).

\section{Materials and Methods}

\section{Animals}

Mature cats of mixed breeds were maintained under controlled light (14-h light : 10-h dark) and temperature $\left(20-23^{\circ} \mathrm{C}\right)$. They were fed a standard commercial ration (Purina) and water ad libitum. The criteria used to determine changes in behaviour, including oestrus, and in the exfoliate vaginal epithelium have been previously described (Shille, Lundström \& Stabenfeldt, 1979). Animals were allowed to undergo at least one oestrous cycle before the ovulatory stimulus on Day 3 or 4 of oestrus. The ovulatory stimulus consisted of coitus with vasectomized males which was limited to $\frac{1}{2} \mathrm{~h} ; 1-4$ coital inputs occurred within this time. Ovarian and endocrine responses to coitus in cats were as variable within animals as between animals, and therefore each oestrous period for animals used twice was reported as an independent observation. Overall hormonal responses were tested by oneway analysis of variance using Scheffés (1959) method of multiple comparisons to detect significant differences amongst groups.

\section{Determination of ovulation}

In the first experiment, ovulation was determined in 14 cycles by gross observation and microscopic examination of ovulatory points on ovaries removed at predetermined intervals after coitus, i.e. at $28 \mathrm{~h}$ ( 3 cats), $32 \mathrm{~h}$ ( 4 cats), $36 \mathrm{~h}$ ( 4 cats) and $40 \mathrm{~h}$ ( 3 cats). Ovaries were prepared for histological examination by a modification of the method developed for the rabbit (Bjersing \& Cajander, 1974) in which the ovary is freed with scissors without stretching or clamping the vessels in the ligamentum latum and immersed in $4 \%$ glutaraldehyde in $0.15 \mathrm{M}$-cacodylate. After $5 \mathrm{~min}$, blocks of tissues containing ovulated follicles were sliced while the ovary was still in the fixative; slices stored in the fixative at $5^{\circ} \mathrm{C}$ were later processed and stained with haematoxylin-eosin. Criteria previously developed to determine the ovulatory endpoint in the rabbit (Markee \& Hinsey, 1935) were adapted for the cat.

In a subsequent experiment the ovulatory process was observed in situ. Changes in follicle size, the number of ovulatory follicles and the time of ovulation were observed in 15 cycles with the aid of a $\times 3-60$ zoom surgical microscope in laparotomized animals anaesthetized with ketamine $\mathrm{HCl}$ (Vetalar: Parke Davis). Ovaries were viewed at 30-min intervals starting at $22 \mathrm{~h}$ after the ovulatory simulus and continuing until ovulation occurred or to $30 \mathrm{~h}$ if ovulation did not occur.

\section{Determination of endocrine events}

The pattern of endocrine change post coitum was determined by analysis of plasma for luteinizing hormone ( $\mathrm{LH}$ ), oestradiol-17 $\beta$ and progesterone in all 29 cycles studied. Blood (3-6 ml) was taken from the jugular vein of unanaesthetized cats just before the ovulatory stimulus $\left(\frac{1}{2} \mathrm{~h}\right.$ or less) which was designated the zero time and at intervals of $\frac{1}{2}, 2,4,6,8,12,16,20$ and $24 \mathrm{~h}$ after stimulation. The plasma was obtained immediately by centrifugation, split into two aliquots for protein and steroid hormone analysis, and frozen at $-20^{\circ} \mathrm{C}$ until assayed. Animals had been conditioned to the bleeding restraint, which involved restraint in a canvas bag and box, for a period of several months before this study. 


\section{LH assay}

Standard. LH was prepared from whole cat pituitaries removed within $1 \mathrm{~h}$ of death, quickly frozen at $-70^{\circ} \mathrm{C}$ and stored at $-20^{\circ} \mathrm{C}$ until extracted. Isolation and purification methods were similar to those previously employed for a variety of mammalian and non-mammalian LHs (Papkoff, Gospodarowicz, Candiotti \& Li, 1965; Papkoff \& Gann, 1970; Licht et al., 1977). In brief, the pituitaries were homogenized in a Waring blender, the $\mathrm{pH}$ adjusted to 9.5 with $\mathrm{CaO}$, and the homogenate extracted at $4^{\circ} \mathrm{C}$ for $3 \mathrm{~h}$. The alkaline extract was separated from the insoluble residue by centrifugation, adjusted to $0.15 \mathrm{M}-\left(\mathrm{NH}_{4}\right)_{2} \mathrm{SO}_{4}$ and to $\mathrm{pH} 4$ by the addition of freshly prepared $\mathrm{HPO}_{3}$. The resulting precipitate (containing $\mathrm{GH}$ ) was removed by centrifugation and the glycoprotein hormones in the supernatant were heat treated $\left(55^{\circ} \mathrm{C}, 2 \mathrm{~min}\right)$ to destroy proteolytic enzymes, and concentrated by extraction with ammonium acetate-ethanol. The dialysed and freeze-dried glycoprotein extract was then chromatographed on DEAE-cellulose equilibrated with $0.03 \mathrm{M}-\mathrm{NH}_{4} \mathrm{HCO}_{3}, \mathrm{pH} 9$. Of the 3 fractions obtained from this chromatographic procedure (see Licht et al., 1977, for detail), LH activity was concentrated in the unabsorbed material. This fraction was freeze-dried and subsequently chromatographed on sulphoethyl Sephadex C-50 equilibrated with $0.03 \mathrm{M}-\mathrm{NH}_{4} \mathrm{HCO}_{3}$. The $\mathrm{LH}$ was absorbed on this column and eluted with $1 \mathrm{M}$ $\mathrm{NH}_{4} \mathrm{HCO}_{3}$. Final purification was achieved by gel filtration on Sephadex G-100 equilibrated with $0.05 \mathrm{M}-\mathrm{NH}_{4} \mathrm{HCO}_{3}$. The $\mathrm{LH}$ eluted with a $\mathrm{V}_{\mathrm{e}} / \mathrm{V}_{\mathrm{o}}$ of 1.6 and the yield was $1.6 \mathrm{mg}(160 \mathrm{mg} / \mathrm{kg})$.

Due to the small amount of LH obtained, limited characterization studies were performed. Examination of LH (F9B) by disc gel electrophoresis in $7.5 \%$ gel at pH 8.3 (Ornstein, 1964) revealed a single, but diffuse, band at an $R_{\mathrm{f}}$ of 0.1 which was similar to patterns obtained with the $\mathrm{LH}$ preparations from sheep, cows, pigs and horses. The absence of any other stained bands was taken to indicate a very low contamination with other pituitary hormones. The potency of F9B in terms of NIH-LH-S1 was $1.8(1.3-2.6,95 \%$ confidence interval) as assessed in the rat interstitial cell testosterone production assay (Dufau, Mendelson \& Catt, 1974). This potency is comparable to those of a variety of other mammalian LHs tested in this same assay (Farmer, Suyama \& Papkoff,

Table 1. Amino acid composition of sheep and cat $\mathrm{LH}$

\begin{tabular}{lcc}
\hline \multicolumn{1}{c}{ Amino acid } & Sheep LH* & Cat LH $\dagger$ \\
\hline Lysine & 12 & $10 \cdot 1$ \\
Histidine & 6 & $2 \cdot 9$ \\
Arginine & 11 & $9 \cdot 9$ \\
Aspartic acid & 11 & $11 \cdot 4$ \\
Threonine & 16 & $13 \cdot 4$ \\
Serine & 14 & $13 \cdot 1$ \\
Glutamic acid & 14 & $15 \cdot 2$ \\
Proline & 27 & $28 \cdot 0$ \\
Glycine & 11 & $16 \cdot 8$ \\
Alanine & 15 & $20 \cdot 9$ \\
Half-cystine & 22 & $20 \cdot 2$ \\
Valine & 13 & $14 \cdot 1$ \\
Methionine & 7 & $4 \cdot 7$ \\
Isoleucine & 7 & $4 \cdot 3$ \\
Leucine & 14 & $15 \cdot 0$ \\
Tyrosine & 7 & $6 \cdot 1$ \\
Phenylalanine & 8 & $8 \cdot 5$ \\
\hline
\end{tabular}

* Calculated from structural analysis, 215 residues (from Papkoff, Sairam, Farmer \& $\mathrm{Li}$, 1973).

† Amino acid analysis : $20 \mathrm{~h}$ hydrolysis, uncorrected for hydrolytic destruction, calculated on the basis of 215 residues per mol. 
1977). An amino acid analysis was performed by the method of Spackman, Stein \& Moore (1958) in an automatic amino acid analyser (Beckman Model 120B). The results are shown in Table 1 with the composition of ovine $\mathrm{LH}$ included for comparison. The only noteworthy difference between cat $\mathrm{LH}$ and the $\mathrm{LH}$ s of other animals was a reduced content of histidine and isoleucine in the cat $\mathrm{LH}$.

Assay. LH was determined by a heterologous radioimmunoassay as described by Follett, Scanes \& Cunningham (1972). Cat LH (F9B), stored as $3500 \mathrm{ng} / 200 \mu \mathrm{l}$ diluent, was used as the reference standard and iodinated ovine LH (LER-1056-C2) was used as the tracer because of the limited quantity of cat LH available. This was possible because displacement curves for the F9B standard were identical when obtained with ${ }^{125} \mathrm{I}$-labelled cat $\mathrm{LH}$ or ${ }^{125} \mathrm{I}$-labelled ovine LH as tracer (Text-fig. 1).

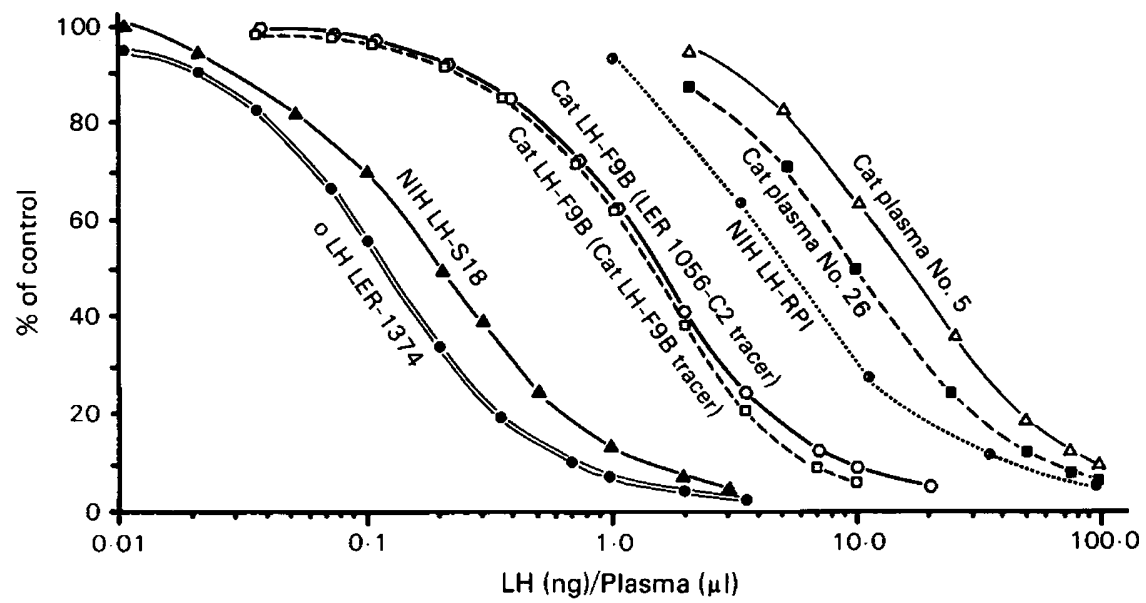

Text-fig. 1. Inhibition curves for cat LH (F9B), ovine LH (LER 1374A and NIH-LH-S18) and rat LH (RPI) using cat LH (F9B) or ovine LH (LER 1056-C2) for iodination and rabbit antiovine LH antiserum (GDN No. 15). The plasmas were obtained from cats after coitus-induced release of $\mathrm{LH}($ Cat $5=147.5 \mathrm{ng} / \mathrm{ml}$; Cat $26=88.8 \mathrm{ng} / \mathrm{ml}$ ).

Highly purified ovine LH (LER-1056-C2, courtesy of Dr L. Reichert) and cat LH (F9B) were each dissolved in $0.5 \mathrm{M}$-phosphate buffer without saline, $\mathrm{pH} 7 \cdot 5$, at a concentration of $5 \mu \mathrm{g}$ in $20 \mu \mathrm{l}$ and iodinated with approximately $1 \mathrm{mCi}^{125} \mathrm{I}$ (Amersham) in the presence of $20 \mu \mathrm{g}$ chloramine $\mathrm{T}$ in $10 \mu \mathrm{l} 0.5 \mathrm{M}$-phosphate buffer. Iodination was stopped after $30-60 \mathrm{sec}$ by the addition of $30 \mu \mathrm{g}$ sodium metabisulphite in $25 \mu \mathrm{l} 0.5 \mathrm{M}$-phosphate buffer. Each mixture was immediately transferred to a previously prepared $10 \mathrm{ml}$ Sephadex $\mathrm{G} 75$ column, and $0.5 \mathrm{ml}$ fractions were eluted with $0.05 \mathrm{M}$ phosphate buffer, $\mathrm{pH} 7.5$. The fraction containing iodinated $\mathrm{LH}$ was stored in $1.0 \mathrm{ml} 3.0 \%$ bovine serum albumin and diluted to 10000 c.p.m. in $50 \mu \mathrm{l}$ for use in the assay.

Rabbit anti-ovine-LH (No. 15, courtesy Dr G. D. Niswender) was diluted to 1:400 with distilled water for storage, and further diluted on the day of the assay to $1: 40000$ with phosphate buffer $(0.04 \mathrm{M}, \mathrm{pH} 7 \cdot 4)$ containing $0.15 \mathrm{M}-\mathrm{NaCl}, 0.01 \mathrm{M}-\mathrm{EDTA}, 0.1 \%$ purified calfskin gelatin (Eastman Kodak) and $0 \cdot 1 \%$ sodium azide (assay diluent). The antiserum (GDN No. 15) has been reported to be specific for LH (Niswender, Reichert, Midgley \& Nalbandov, 1969) in a variety of species (Millar \& Gehnelt, 1977).

Plasma samples $(50 \mu \mathrm{l})$, or different amounts of the cat LH standard (F9B), were added to the tubes and made up to a volume of $200 \mu \mathrm{l}$ in the assay diluent; $50 \mu \mathrm{LH}$ antiserum $(1: 40000$ in assay diluent) and $50 \mu 1$ 1:200 normal rabbit serum in assay diluent were also added. After $24 \mathrm{~h},{ }^{125} \mathrm{I}$ labelled LH (LER-1056-C2) was added to all tubes at a concentration of 10000 c.p.m. per $50 \mu 1$ assay diluent. This was allowed to incubate overnight before $50 \mu \mathrm{l}$ of a $1: 25$ dilution of sheep antirabbit gamma globulin (Antisera for Science, New Rochelle, New York) was added which was 
followed by another $24 \mathrm{~h}$ incubation period. The total assay volume was $350 \mu \mathrm{l}$. Each plasma sample was assayed in triplicate and each concentration of the standard curve was done in quadruplicate. Samples with concentrations higher than $10.0 \mathrm{ng}$ on the dose-response curve were re-run with a smaller plasma volume $(10 \mu \mathrm{l})$.

The quantity of iodinated ovine LH bound by the antibody used in the assay (GDN No. 15, dilution 1:40000) ranged from 30.6 to $38 \%$ while non-specific binding was $2.3 \%$. Under the conditions of the assay, the useful range of the standard curve extended from $0 \cdot 1$ to $10.0 \mathrm{ng}$ cat $\mathrm{LH} /$ tube and the minimum detectable concentration of $\mathrm{LH}$ in cat plasma was $2.0 \mathrm{ng} / \mathrm{ml}$. Using ratios between replicate determinations, the mean intra-assay coefficient of variation was $9.5 \%$ $(\mathrm{n}=21)$. The interassay coefficient of variation for plasma samples containing $5-100 \mathrm{ng} / \mathrm{ml}$ was $11 \cdot 1 \%(n=14)$ and $100-1000 \mathrm{ng} / \mathrm{ml}$ was $16 \cdot 7 \%(n=14)$.

Parallel standard dose-response curves were obtained from the sheep and cat standards with ${ }^{125}$ I-labelled sheep and cat LH (Text-fig. 1). Curves parallel to these standards were also observed for the LH preparations NIH-S18 and NIH-RP1; relative to these, cat LH had a potency of 0.39 $(0 \cdot 31-0 \cdot 49,95 \%$ confidence interval) and $105(93-119)$, respectively. Inhibition curves parallel to the cat $\mathrm{LH}$ were obtained using serial dilutions of 2 different pools of cat plasma obtained post coitum (Text-fig. 1).

LH levels were determined, by radioimmunoassay and the rat interstitial cell assay, in pools of plasma obtained post coitum from 11 cats with $\mathrm{LH}$ concentrations ranging from about 200 to 600 $\mathrm{ng} / \mathrm{ml}$. Means of the values determined by the two methods did not differ significantly $(P=0.45)$ when tested by Student's $t$ test for paired samples; the correlation coefficient was $r=0.997$.

\section{Steroid assays}

Concentrations of plasma oestradiol and progesterone were determined by radioimmunoassay methods described and validated previously (Shille et al., 1979; Shille \& Stabenfeldt, 1979). The practical detection limits for these steroids were established as the mean $+2 \times$ s.d. of the concentrations measured in the plasma of ovariectomized cats, i.e. $6 \mathrm{pg}$ oestradiol $/ \mathrm{ml}$ and $80 \mathrm{pg}$ progesterone $/ \mathrm{ml}$. A coefficient of variation of $20 \%$ was found for an oestradiol plasma pool which contained $30 \mathrm{pg} / \mathrm{ml}(n=26)$. The variation between duplicate samples containing $<16$ or $20-35 \mathrm{pg}$ oestradiol $/ \mathrm{ml}$ in plasma was 13 and $9 \%$, respectively. The interassay coefficient of variation was $16 \%(n=17)$ for progesterone as measured in pooled plasma from an ovariectomized cat with a mean of $101 \mathrm{pg}$ progesterone/ml. The within-assay variability was $12 \%$ for replicates in the range from 0.5 to $1.0 \mathrm{ng} / \mathrm{ml}$, and $7 \%$ for $1-20 \mathrm{ng} / \mathrm{ml}$.

\section{Results}

\section{Ovulation}

Ovulation was induced by coitus in 17 of 29 cycles after one ( 6 cycles), 2 ( 5 cycles), 3 ( 3 cycles) and 4 ( 3 cycles) coital inputs. In the first experiment, ovaries were removed from 14 cats at 28,32 , 36 and $40 \mathrm{~h}$ post coitum; 10 animals had ovulated and there was a total of 26 ovulated follicles (corpora haemorrhagica) on one or both ovaries. Serial sections of ovulated follicles showed that ovulation had been completed and organization of the corpus haemorrhagicum was in progress as early as $28 \mathrm{~h}$ post coitum in $1 / 3,1 / 1$ and $2 / 2$ follicles ( 3 of 3 cats), at $32 \mathrm{~h}$ in $2 / 6,2 / 2$ and $5 / 5$ follicles ( 3 of 4 cats), at $36 \mathrm{~h}$ in $6 / 6$ follicles ( 2 of 4 cats) and at $40 \mathrm{~h}$ in $7 / 7$ follicles ( 2 of 3 cats). Ovulated follicles had ovulation craters that were bounded by extruded mural theca and granulosa cells which formed a loose reticulum. The surface epithelium was undermined by eosinophilic homogeneous material suggesting the presence of oedema. Unovulated, mature follicles (3-4 mm diameter) that were grey, flattened and spherical in appearance were seen on ovaries that showed ovulatory points as well as in some ovaries from animals that did not ovulate. 
In the second experiment, ovaries were observed in situ in 15 cycles every $30 \mathrm{~min}$ from 22 to $30 \mathrm{~h}$ post coitum; ovulation occurred in 7 cycles. No ovulatory points were present at $22 \mathrm{~h}$. The first signs of the ovulatory process were observed at $23 \mathrm{~h}$ post coitum with the first ovulation complete at $25 \mathrm{~h}$. The interval from the first coital stimulus to the end of ovulation ranged from 27 to $29 \mathrm{~h}$. The entire process of ovulation was observed in 4 cycles (mature follicle to corpus haemorrhagicum) during 23-28 h ( 3 follicles), 23-27 h ( 2 follicles), 25-28 h ( 3 follicles) and 25-29 h ( 3 follicles) post coitum. Ovulation of up to 3 follicles was completed within a 3-5 h period in the 4 animals that were observed during the entire process. By $29 \mathrm{~h}, 21$ of 21 mature follicles ( 7 cycles) that had undergone distinct structural change had ovulated. The number of coital inputs did not affect the interval from coitus to ovulation. In 8 cycles no ovulations were observed during the 8 h observation period; ovulatory failure was confirmed by the subsequent determination of plasma progesterone concentrations.

At the earliest observation time of ovaries in situ ( $22 \mathrm{~h}$ post coitum), mature follicles measured $3-$ $6 \mathrm{~mm}$ at the greatest diameter and were dark grey in colour in contrast to the ivory-yellow of the surrounding ovarian stroma. Follicles that later ovulated could not be distinguished at this time from non-ovulatory follicles. Dilated branched capillaries surrounding a translucent pale area were seen in ovulatory follicles $2-3 \mathrm{~h}$ before ovulation ( 11 follicles, 4 cycles), but not in 6 other follicles on the same ovaries that were $3 \mathrm{~mm}$ in diameter and which subsequently failed to complete the ovulatory process. The first sign of approaching ovulation was the development of a cone shaped protuberance in the translucent area which became diffusely reddened. This occurred in $<\frac{1}{2} \mathrm{~h}$ ( 5 follicles, 2 cycles) or $\frac{1}{2}-1$ h ( 6 follicles, 2 cycles) before ovulation when the domed apex gradually collapsed aroung the edge leaving a small depression in the centre. Delicate strands of fibrin occasionally adhered to the remaining tip of the dome. Extrusion of the cumulus was not observed. Mature follicles that failed to ovulate in response to coitus ( 13 follicles, 8 cycles) did not change in size or appearance during the period of observation. Immature follicles $(<2 \mathrm{~mm} \mathrm{diam}$.) were observed on most of the ovaries at all times.

\section{LH secretion patterns}

The mean \pm s.d. plasma levels of $\mathrm{LH}$ determined before coital stimulation in the 29 cats were $19.9 \pm 6.6 \mathrm{ng} / \mathrm{ml}(n=121)$. The level of discrimination for LH was established as the mean \pm s.d. or $30 \mathrm{ng} / \mathrm{ml}$. Surges of LH were induced in 18 of 29 cycles after coitus; ovulation occurred in 17 of these animals. Two types of $\mathrm{LH}$ release occurred in the responding animals (Text-fig. 2 ). In the first type (long surge), mean plasma LH concentrations in 11 cycles rose to $616 \pm 180 \mathrm{ng} / \mathrm{ml}$ at $\frac{1}{2} \mathrm{~h}$ and to $941 \pm 154 \mathrm{ng} / \mathrm{ml}$ at $2 \mathrm{~h}$ post coitum, with a return to baseline not occurring until 16-20 h post coitum. Six animals had a second type of LH release, i.e. short surge, with values of $537 \pm 218 \mathrm{ng} / \mathrm{ml}$ at $\frac{1}{2} \mathrm{~h}$ and $353 \pm 245 \mathrm{ng} / \mathrm{ml}$ plasma at $2 \mathrm{~h}$ post coitum. At $4 \mathrm{~h}$ post coitum LH concentrations in all 6 cats declined to near baseline with an average of $49 \pm 18 \mathrm{ng} / \mathrm{ml}$. One cat which failed to ovulate showed sporadic peaks of $\mathrm{LH}$ that reached 224,157 and $287 \mathrm{ng} / \mathrm{ml}$ at 4, 6 and $12 \mathrm{~h}$ post coitum, respectively.

Coitus failed to initiate an LH surge in 11 cycles. Plasma LH levels were not elevated above the $95 \%$ confidence interval calculated for baseline concentrations at any time during the observation periods. The average number of coital stimuli for cats with a long, short or no LH surge was $2 \cdot 0$, $2 \cdot 25$ and $2 \cdot 5$, respectively.

The LH secretion pattern of one cat is shown in Text-fig. 3(a). Cat 22 had a long LH surge after two coital inputs with $\mathrm{LH}$ concentrations reaching $290,616,424$ and $367 \mathrm{ng} / \mathrm{ml}$ at $\frac{1}{2}, 2,4$ and $6 \mathrm{~h}$ after coitus, respectively, and remaining above $100 \mathrm{ng} / \mathrm{ml}$ at 8 and $12 \mathrm{~h}$ with a decline to $22 \mathrm{ng} / \mathrm{ml}$ plasma at $16 \mathrm{~h}$ post coitum. Text-figure 3(b) depicts a short $\mathrm{LH}$ surge observed in Cat 46 after one coital stimulus. LH rose to $1960 \mathrm{ng} / \mathrm{ml}$ at $\frac{1}{2} \mathrm{~h}$, declining to $200 \mathrm{ng} / \mathrm{ml}$ at $2 \mathrm{~h}$ and to $27 \mathrm{ng} / \mathrm{ml}$ by $4 \mathrm{~h}$ post coitum. An apparent biphasic release of LH occurred in Cat 40 (Text-fig. 3c) in which the first LH peak was at $\frac{1}{2} \mathrm{~h}(630 \mathrm{ng} / \mathrm{ml})$ and the second at $6 \mathrm{~h}(595 \mathrm{ng} / \mathrm{ml})$ post coitum; the animal subsequently ovulated. An example of failure to release $\mathbf{L H}$ following coitus is shown in Text-fig. 3(d). 


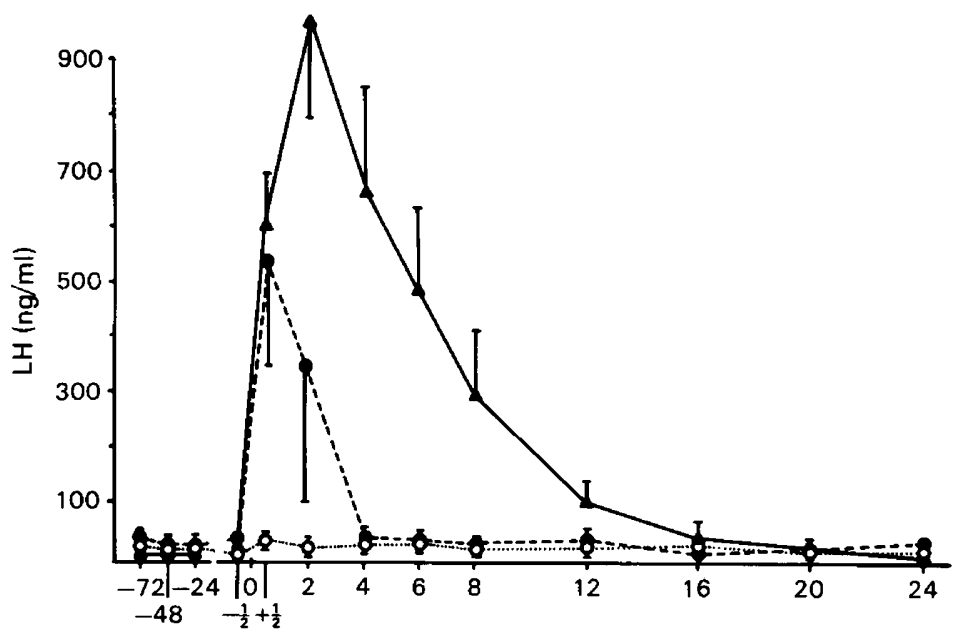

Hours before (-) and after coitus

Text-fig. 2. Mean \pm s.e.m. plasma $\mathbf{L H}$ concentrations in cats that failed to release $\mathbf{L H}$ $\left(\mathrm{O}^{---} \mathrm{O}, n=5\right)$, or released LH over a 4-h period $\left(0_{---}, n=6\right)$ or a 16-h period $(\mathbf{\Lambda}--\mathbf{\Lambda}, n=11)$. The zero time was the first coital input (subsequent coital inputs varied from $0-3$ within a 30 -min interval). The vertical bars represent s.e.m.

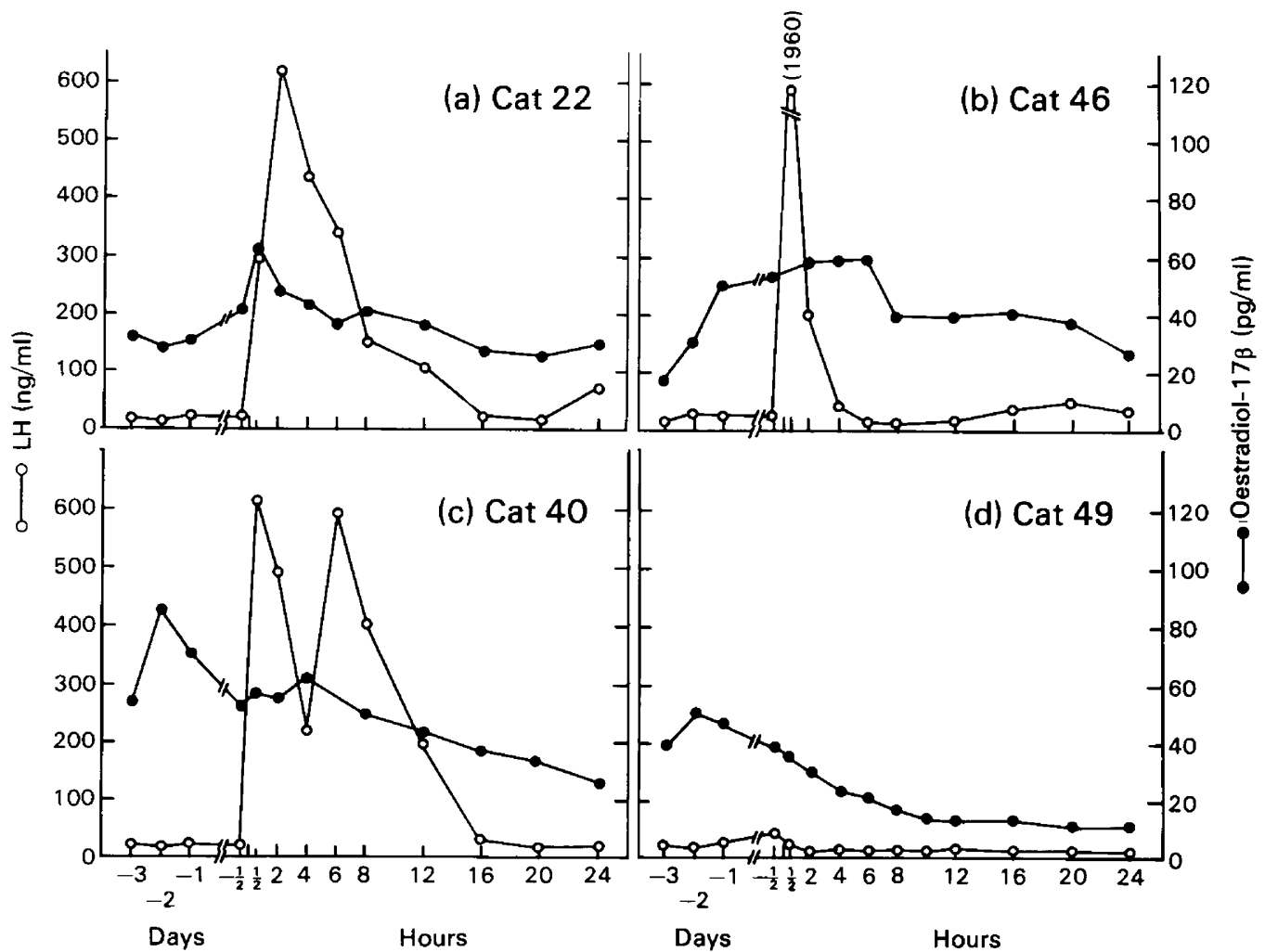

Text-fig. 3. Plasma hormone concentrations in cats after coitus (zero time represents the first coital input). (a) Example of a long-duration surge of LH after 2 intromissions; (b) example of a short-duration surge of $\mathrm{LH}$ after 1 intromission; (c) a biphasic LH response after 4 intromissions; and (d) no LH release in spite of 3 intromissions. 


\section{Ovarian steroids}

Oestradiol-17 $\beta$ levels in plasma of individual cats (Text-fig. 3) generally declined during the period of observation. Cats that ovulated after coitus showed a decline in oestrogen levels between the 6th and 8th $\mathrm{h}$ with the first significant decline $(P<0.05)$ observed at $16 \mathrm{~h}$ post coitum (Table 2). These changes occurred regardless of the duration of the LH surge. Significance of responses was tested by Sheffe's (1959) method of multiple comparisons in which oestrogen values were pooled for the first four sampling periods (coitus through 6 th $h$ ) and compared with each subsequent postcoital sampling period.

Table 2. Oestradiol-17 $\beta$ plasma concentrations in cats before and after coitus

\begin{tabular}{ll}
\hline \multicolumn{1}{c}{ Time } & Oestradiol-17ß $(\mathrm{pg} / \mathrm{ml})$ \\
\hline$-24 \mathrm{~h}$ & $41 \cdot 1 \pm 3 \cdot 9(16)$ \\
Coitus $\left( \pm \frac{1}{2} \mathrm{~h}\right)$ & $44 \cdot 1 \pm 6 \cdot 2(14)$ \\
$+2 \mathrm{~h}$ & $53 \cdot 4 \pm 6 \cdot 2(12)$ \\
$+4 \mathrm{~h}$ & $52 \cdot 1 \pm 6 \cdot 8(13)$ \\
$+6 \mathrm{~h}$ & $51 \cdot 1 \pm 4 \cdot 9(14)$ \\
$+8 \mathrm{~h}$ & $44 \cdot 2 \pm 5 \cdot 0(12)$ \\
$+12 \mathrm{~h}$ & $40 \cdot 3 \pm 3 \cdot 7(15)$ \\
$+16 \mathrm{~h}$ & $32 \cdot 3 \pm 2 \cdot 6^{*}(15)$ \\
$+20 \mathrm{~h}$ & $27 \cdot 5 \pm 2 \cdot 5^{*}(13)$ \\
$+24 \mathrm{~h}$ & $26 \cdot 2 \pm 1 \cdot 9^{*}(14)$ \\
\hline
\end{tabular}

Values are mean \pm s.e.m. for the no. of samples indicated in parentheses.

* Significantly different from values obtained at coitus and through the first $6 \mathrm{~h}, P<0.05$ (see text for explanation of statistical method).

Plasma progesterone levels remained at baseline concentrations of $123 \pm 62 \cdot 4 \mathrm{pg} / \mathrm{ml}(n=24)$ during the $24-\mathrm{h}$ period after the ovulatory stimulus. The initial increase in progesterone was detected at 48 or $72 \mathrm{~h}$ following a successful ovulatory stimulus.

\section{Coital behaviour}

Coital inputs were limited to the number which could be accomplished by the males within $\frac{1}{2} \mathrm{~h}$ and ranged from 1 to 4 , with one mating occurring in 10 cycles, 2 in 8 cycles, 3 in 6 cycles and 4 in 5 cycles.

Males mounted oestrous females for an average of 2 min before intromission $(2 \cdot 0 \pm 1 \cdot 5, n=29$, range 0.5 to $7 \mathrm{~min}$ ). Intervals between intromissions ranged from 1 to $60 \mathrm{sec}$ with a mean of $12.3 \pm$ $10 \cdot 6 \sec (n=29)$.

\section{Discussion}

The interval between coital stimulation and ovulation has been reported to be variable in the cat, ranging from 25 to $50 \mathrm{~h}$ as determined by observations of ovaries removed from cats at intervals after coitus (Longley, 1911; Courrier \& Gros, 1933; Dawson \& Friedgood, 1940). However, in many cases, the data presented do not preclude an earlier occurrence of ovulation. Wildt et al. (1981) used laparoscopy at 48-h intervals to determine the time of ovulation in response to coital stimuli ( 3 at 4-h intervals) which were repeated daily as long as the females were in oestrus; ovulation occurred in 5 of 12 cycles ( 6 cats) at the first observation period $(48 \mathrm{~h})$ with ovulation confirmed 
in the other 7 cycles at the second observation period (at $96 \mathrm{~h}$ ). It was concluded that ovulation occurs between 44 and $60 \mathrm{~h}$ following the first induced LH peak (48-64 h post coitum).

In the present study ovulation occurred as early as $25 \mathrm{~h}$ post coitum after coitus-induced LH release, with most follicles having ovulated by $32 \mathrm{~h}$ post coitum. We previously have found a variable response of $\mathrm{LH}$ release to coital stimulation with some some cats not releasing an ovulatory amount of $\mathbf{L H}$ until the 2nd, 3rd or even 4th day of oestrus (Banks \& Stabenfeldt, 1982). It is possible that in the study by Wildt et al. (1981) the ovulatory release of LH occurred after the first day of coital stimulation, although the composite LH results indicate that most animals had significant release of $\mathrm{LH}$ on the first day of oestrus. It is more likely that the time of observation of ovaries post coitum is the main cause for the difference reported for the coitus to ovulation interval.

An interval to ovulation of $30-36 \mathrm{~h}$ after the onset of oestrus has been reported for a number of spontaneously ovulating species. Quirke, Hanrahan \& Gosling (1981) observed ovulation in sheep as early as $22 \mathrm{~h}$ after onset of oestrus with $34 / 35$ animals ovulating by $32 \mathrm{~h}$. Also, Parsons, Hunter \& Rayner (1967) reported average ovulation times of $26-30 \mathrm{~h}$ in sheep. Signoret, du Mesnil du Buisson \& Mauléon (1972) observed ovulation between $34 \cdot 1$ and $35.0 \mathrm{~h}$ after the onset of oestrus in mated pigs. Marion, Smith, Wiley \& Barrett (1950) reported the interval to ovulation in mated cattle from the onset of oestrus to be about $26 \mathrm{~h}$. Because the onset of oestrus and the initiation of the ovulatory release of $\mathrm{LH}$ occur at about the same time in these species, the $\mathrm{LH}$ release to ovulation interval in these species is comparable to that which we have observed for the cat. In addition, an interval of $32 \mathrm{~h}$ from the LH rise to ovulation has been reported for women (W.H.O., 1980).

The mode of preovulatory LH release in spontaneously ovulating animals has been shown to be one of increased frequency of pulsatile release. Oestrogen, in increasing concentration over a period of time (hours), is required for this phenomenon through the sensitization of LH-RH neurones in the hypothalamus (Neill, Patton, Dailey, Tsou \& Tinedall, 1977) and/or gonadotrophs of the anterior pituitary (Nakia, Plant, Hess, Keogh \& Knobil, 1978). In contrast, LH release in the cat appears to be continuous after coitus (Johnson \& Gay, 1981b), although pulsatile at other times of the oestrous cycle (Johnson \& Gay, 1981a).

Johnson \& Gay (1981b) observed a refractoriness of LH release which began about 90 min after the initial coital input regardless of the number of coital inputs. This agrees with our findings of peak concentrations of $\mathrm{LH}$ at $2 \mathrm{~h}$ although coital inputs were limited to a maximum of four which occurred within the first $30 \mathrm{~min}$ of contact. Wildt et al. (1981), however, found that LH release could be enhanced when coital inputs were repeated at $4-h$ intervals. This suggests that the refractory period may be relatively short in cats.

Coitus appears to influence the dynamics of LH release in spontaneously ovulating animals as well as in induced ovulators. Marion et al. (1950) found that ovulation occurred sooner in cows after the onset of oestrus if mating was allowed $(28.8 \mathrm{~h}$ compared with $32 \cdot 1 \mathrm{~h}$ in unmated controls). In sows mating decreased the interval from the onset of oestrus to the start and finish of ovulation (34.1 and $38.0 \mathrm{~h}$, respectively) as compared to unmated controls ( 35.0 and $41.8 \mathrm{~h}$, respectively) (Signoret et al., 1972). These results suggest that coitus in the cow and sow enhances and/or accelerates the preovulatory release of $\mathbf{L H}$. It has been shown in the rat that coitus does not affect the initial preovulatory surge of LH, but does extend the duration of LH release (Moss, Dudley \& Schwartz, 1977).

The concentrations of LH reported in this study are similar to those reported by Johnson \& Gay (1981a, b) who used the NIAMDD RP-1 rat standard whereas we used a cat LH reference standard. These concentrations are about 10 -fold higher than those reported by Concannon $e t$ al. (1980) who used an ovine LH reference standard. When we have used ovine LH as both standard and tracer for cat LH determinations (Banks \& Stabenfeldt, 1982), the LH values are about $10 \%$ of those reported in the present study. It is likely that $\mathrm{LH}$ values reported for some animals will change as species-specific LH becomes available for reference purposes. The use of an homologous standard as in the current study is desirable for the development of LH data for a particular species.

It is unclear why some cats in this experiment had relatively short LH surges after coital 
stimulation (6/18). The duration of the LH surge was not affected by the number of preovulatory follicles present, the duration of mounting, the number of intromissions, or the use of a particular male. Some of the animals in our study released large amounts of LH in response to only 1 coital input. Thus one coital stimulus requiring only a few seconds can elicit a relatively sustained release of $\mathrm{LH}$ in the cat. It is also apparent that $\mathrm{LH}$ surges which lasted $2-4 \mathrm{~h}$ were sufficient to produce ovulation. The amount of $\mathrm{LH}$ required per unit of time to cause ovulation in the cat is about 6 times greater than the minimal ovulatory requirement (Banks \& Stabenfeldt, 1982), and it is obvious that the cat does not require a prolonged release of $\mathrm{LH}$ as a prerequisite for ovulation.

This work was supported in part by the Animal Protection Institute of America, Sacramento, California, and Companion Animal Research Laboratory, School of Veterinary Medicine, University of California, Davis, California.

We thank Brian Davis, Liz Greenlees, Mike Mulvany, Sharon Zito and Dr Lorraine Rose for assistance with the experiments; Dr Peter Wang and Tom Madley for steroid analyses; A. A. Kassam and B. L. Lasley, Research Department, San Diego Zoo, San Diego, California, for the rat interstitial cell assays; and Claire Ogata, Sharon Zito and Cindee Worland for help with the manuscript.

\section{References}

Banks, D.H. \& Stabenfeldt, G.H. (1982) Luteinizing hormone release in the cat in response to coitus on consecutive days of estrus. Biol. Reprod. 26, 603-611.

Bjersing, L. \& Cajander, S. (1974) Ovulation and the mechanism of follicle rupture. I. Light microscopic changes in rabbit ovarian follicles prior to induced ovulation. Cell Tiss. Res. 149, 287-300.

Bonney, R.C., Moore, H.D.M. \& Jones, D.M. (1981) Plasma concentrations of oestradiol- $17 \beta$ and progesterone, and laparoscopic observations of the ovary in the puma (Felis concolor) during oestrus, pseudopregnancy and pregnancy. J. Reprod. Fert. 63, 523531.

Concannon, P., Hodgson, B. \& Lein, D. (1980) Reflex LH release in estrous cats following single and multiple ovulations. Biol. Reprod. 23, 111-117.

Courrier, R. \& Gros, G. (1933) Données complémentaires sur le cycle génital de la chatte. C. r. Séanc. Soc. Biol. 114, 275-277.

Dawson, A.B. \& Friedgood, H.B. (1940) The time and sequence of preovulatory changes in the cat ovary after mating or mechanical stimulation of the cervix uteri. Anat. Rec. 76, 411-429.

Dufau, M.L., Mendelson, C.R. \& Catt, K.J. (1974) A highly sensitive in vitro bioassay for luteinizing hormone and chorionic gonadotropin: testosterone production by dispersed Leydig cells. J. clin. Endocr. Metab. 39, 610-613.

Farmer, S.W., Suyama, A. \& Papkoff, H. (1977) Effect of diverse mammalian and nonmammalian gonadotropins on isolated rat Leydig cells. Gen. comp. Endocr. 32, 488-494.

Follett, B.K., Scanes, C.G. \& Cunningham, F.J. (1972) A radioimmunoassay for avian luteinizing hormone. $J$. Endocr. 52, 359-378.

Foster, M.A. \& Hisaw, F.L. (1935) Experimental ovulation and the resulting pseudopregnancy in anoestrous cats. Anat. Rec. 62, 75-93.
Friedgood, H.B. \& Dawson, A.B. (1940) Physiological significance and morphology of the carmine cell in the cat's anterior pituitary. Endocrinology 26, 10221031.

Johnson, L.M. \& Gay, V.L. (1981 a) Luteinizing hormone in the cat. I. Tonic secretion. Endocrinology 109, 240 246.

Johnson, L.M. \& Gay, V.L. (1981 b) Luteinizing hormone in the cat. II. Mating-induced secretion. Endocrinology 109, 247-252.

Licht, P., Papkoff, H., Farmer, S.W., Muller, C.H., Isin, H.W. \& Crews, D. (1977) Evolution of gonadotropin structure and function. Recent Prog. Horm. Res. 33, 169-243.

Longley, W.H. (1910) Factors which influence the maturation of the egg and ovulation in the domestic cat. Science, N.Y. 31, 465-466.

Longley, W.H. (1911) The maturation of the egg and ovulation in the domestic cat. Am. J. Anat. 12, 139172.

Marion, G.B., Smith, V.R., Wiley, T.E. \& Barrett, G.R. (1950) The effect of sterile copulation on time of ovulation in dairy heifers. J. Dairy Sci. 33, 885-889.

Markee, J.E. \& Hinsey, J.C. (1935) Observations on ovulation in the rabbit. Anat. Rec. 64, 309-319.

Millar, R.P. \& Gehnelt, C. (1977) Application of ovine luteinizing hormone $(\mathrm{LH})$ radioimmunoassay in the quantitation of LH in different mammalian species. Endocrinology 101, 760-768.

Moss, R.L., Dudley, C.A. \& Schwartz, N.B. (1977) Coitus-induced release of luteinizing hormone in the proestrous rat: fact or fantasy? Endocrinology 100, 394-397.

Nakia, Y., Plant, T.M., Hess, D.L., Keogh, E.J. \& Knobil, E. (1978) On the sites of the negative and positive feedback actions of estradiol in the control of the gonadotropin secretion in the rhesus monkey. Endocrinology 102, 1008-1014. 
Neill, J.D., Patton, J.M., Dailey, R.A., Tsou, R.C. \& Tinedall, G.T. (1977) Luteinizing hormone releasing hormones (LHRH) in pituitary stalk blood of rhesus monkeys: relationships to level of $\mathrm{LH}$ release. Endocrinology 101, 430-434.

Niswender, G.D., Reichert, L.E., Jr, Midgley, A.R., Jr \& Nalbandov, A.V. (1969) Radioimmunoassay for bovine and ovine luteinizing hormone. Endocrinology 84, 1166-1173.

Ornstein, L. (1964) Disc electrophoresis-I. Ann. N.Y. Acad. Sci. 121, 321-349.

Papkoff, H. \& Gann, J. (1970) Bovine interstitial cellstimulating hormone: purification and properties. Arch. Biochem. Biophys. 136, 522-528.

Papkofi, H., Gospodarowicz, D., Candiotti, A. \& Li, C.H. (1965) Preparation of ovine interstitial cell-stimulating hormone in high yield. Arch. Biochem. Biophys. 111, 431-438.

Papkoff, H., Sairam, M.R., Farmer, S.W. \& Li, C.H. (1973) Studies on the structure and function of interstitial cell-stimulating hormone. Recent Prog. Horm. Res. 29, 563-588.

Parsons, S.D., Hunter, G.L. \& Rayner, A.A. (1967) Use of probit analysis in a study of the effect of the ram on time of ovulation in the ewe. J. Reprod. Fert. 14, 7180.

Quirke, J.F., Hanrahan, J.P. \& Gosling, J.P. (1981) Duration of oestrus, ovulation rate, time of ovulation and plasma LH, total oestrogen and progesterone in Galway adult ewes and ewe lambs. J. Reprod. Fert. 61, 265-272.

Scheffé, H. (1959) Analysis of Variance, pp. 66-67. John Wiley and Sons, New York.

Shille, V.M. \& Stabenfeldt, G.H. (1979) Luteal function in the domestic cat during pseudopregnancy and after treatment with prostaglandin $\mathrm{F}_{2 \alpha}$. Biol. Reprod. 21, 1217-1223.

Shille, V.M. \& Stabenfeldt, G.H. (1980) Current concepts in reproduction of the $\mathrm{dog}$ and cat. In Advances in Veterinary Science and Comparative Medicine, Vol. 24, pp. 211-243. Eds C. A. Brandley \& C. E. Cornelius. Academic Press, New York.

Shille, V.M., Lundström, K. \& Stabenfeldt, G.H. (1979) Follicular function in the domestic cat as determined by estradiol-17 concentrations in plasma: relation to estrous behavior and cornification of exfoliate vaginal epithelium. Biol. Reprod. 21, 953-963.

Signoret, J.P., du Mesnil du Buisson, F. \& Mauléon, P. (1972) Effect of mating on the onset and duration of ovulation in the sow. J. Reprod. Fert. 31, 327-330.

Spackman, D.H., Stein, W.H. \& Moore, S. (1958) Automatic recording apparatus for use in the chromatography of amino acids. Analyt. Chem. 30, 1190-1206.

W.H.O. (1980) Temporal relationships between ovulation and defined changes in the concentration of plasma estradiol-17\%, luteinizing hormone, folliclestimulating hormone, and progesterone. Am. J. Obstet. Gynec. 138, 383-390.

Wildt, D.E. \& Seager, S.W.J. (1978) Ovarian response in the estrual cat receiving varying doses of $\mathrm{HCG}$. Horm. Res. 9, 144-150.

Wildt, D.E., Platz, C.C., Chakraborty, P.K. \& Seager, S.W.J. (1979) Oestrus and ovarian activity in a female jaguar (Panthera onca). J. Reprod. Fert. 56, 555-558.

Wildt, D.E., Seager, S.W.J. \& Chakraborty, P.K. (1980) Effect of copulatory stimuli on incidence of ovulation and on serum luteinizing hormone in the cat. Endocrinology 107, 1212-1217.

Wildt, D.E., Chan, S.Y.W., Seager, S.W.J. \& Chakraborty, P.K. (1981) Ovarian activity, circulatory hormones, and sexual behavior in the cat. I. Relationships during the coitus-induced luteal phase and the estrous period without mating. Biol. Reprod. 25, 1528.

Received 16 November 1982 